\title{
Phylogenetic Evidence of the Public and Veterinary Health Threat of Dog Rabies in Nigeria
}

\author{
${ }^{1 " O G O, ~ M . ~ F ., ~}{ }^{2}$ NEL, L. H., ${ }^{3}$ SABETA, C. T.
}

${ }^{1}$ Rabies Unit, Viral Research Division National Veterinary Research Institute, PMB 01 Vom Plateau State Nigeria ${ }^{2}$ Microbiology and Plant Pathology, University of Pretoria, 0002 Pretoria, South Africa ${ }^{3}$ Rabies Unit, Onderstepoort Research Institute, P. M. B X5, Onderstepoort, South Africa *Corresponding author: fjmariam@yahoo.com, +234 (0) 7066314000

\begin{abstract}
SUMMARY
Molecular phylogenetics has been utilised to trace spillovers of rabies infection from reservoir host species to dead-end non-reservoirs including humans and other susceptible mammalian species. In this study we demonstrate phylogenetic evidence of the transmission of rabies virus infection from a reservoir host to humans and other animals. Here, we analysed phylogenetically a partial region of the nucleoprotein gene of 33 representative Nigerian rabies viruses predominantly recovered from dogs. The analyses revealed monophyletic group with 2 subclusters according to geographical locality of origin of the viruses. Furthermore, a correlation between humandependent activities such as movement was observed. The data indicated that the virus isolates analysed here together with sequence obtained from Genbank of a human (Nigerian) formed one dominant group. This finding could be attributable to migration and translocation of animals infected with these rabies strains across the country. These molecular epidemiological data further contribute to depicting the public and veterinary health threat that rabies still poses in Nigeria and its implication to food security in this developing economy.
\end{abstract}

KEY WORDS: Nucleoprotein; Phylogenetics; Rabies virus; Nigeria

\section{INTRODUCTION}

The causative agent of rabies is a highly neurotropic virus that is generally transmitted through bites from infected animals to susceptible host species (Knobel et al., 2005). Rabies belongs to the Lyssavirus genus of the family Rhabdoviridae. Seven genotypes are currently recognised within this genus based on antigenic characterization of panels of lyssaviruses (Tordo et al., 2006). These include classical rabies (RABV) GT1, Lagos bat virus (LBV) GT2, Mokola virus (MOKV), GT3, Duvenhage (DUVV) GT4, European bat lyssavirus types-1 and 2 (EBLV-1, GT5 \& EBLV-2, GT6) and Australian bat lyssavirus (ABLV) GT7. The RABV consists of a single-stranded RNA genome of approximately $12 \mathrm{~kb}$ in length (Tordo, 1996a). It codes for 5 viral proteins which include the nucleoprotein (N), the phosphoprotein $(\mathrm{P})$, the matrix protein $(\mathrm{M})$, the glycoprotein (G) and the RNA dependent polymerase (L) (Tordo et al., 1986a). The N gene of lyssaviruses is prime target for many applications including diagnosis (Dean et al., 1996) and the elucidation of the epidemiological and evolutionary relationships of lyssaviruses (Kissi et al., 1995; Sabeta et al., 2007).

Canine rabies in Nigeria still constitutes a significant public health threat as in most developing countries. In these countries, domestic dogs are the principal reservoir and maintenance host species responsible for the transmission of the disease to humans and other domestic animals (Fagbami et al., 1981; Ogunkoya et al., 1984 and Obegbulum, 1994). Wildlife host species are pivotal in the epidemiology of rabies in many countries, but in this country their exact role is still poorly understood and information on wildlife rabies is scanty (Umoh and Belino, 1978).

Globally, at least 55,000 human deaths are believed to occur every year (WHO, 2005) with $99 \%$ of the deaths occurring in the developing countries of Africa and Asia. In Nigeria, an estimated 10, 000 human rabies cases occur annually (Nawathe, 1980). The first documented official report of rabies in human was in 1912 (Boulger and Hardy, 1960). Accurate statistics of both human and animal 
rabies are limited primarily due to misdiagnosis, underreporting and a lack of national rabies surveillance system. All these result in underestimation of the true incidence of the disease. This study presents evidence of the domestic dog to being a perpetual threat to public and veterinary health.

\section{MATERIALS AND METHODS Viral isolates}

Original brain tissue specimen recovered from infected animals including dogs, a cat and a goat submitted for rabies diagnosis in the Rabies Diagnostic Unit of the National Veterinary Research Institute, Vom, Nigeria and collected between 1989 and 2008 were included in the investigation. The brain tissues were kept frozen and transported as original brain samples to the Rabies Unit of the Ondersterpoort Veterinary Institute, Republic of South Africa. These samples on arrival were confirmed as rabies infected by fluorescent antibody test (FAT) ((Dean et al., 1996) and stored at -20C prior to molecular characterization. All virus isolates and their epidemiological information are shown in Table I.

RNA extraction, RT-PCR and viral sequencing Total viral RNA was extracted from approximately 50-100 ng infected brain tissue using Tri reagent according to the supplier's instructions (Sigma, USA). The RNA pellets were solubilised in RNA ribonuclease-free sterile water (RNAsecure suspension solution, Ambion). Reverse transcription was performed using protocols as described previously (Markotter et al., 2006; Sabeta et al., 2007)using primer Lys001 (+) 5ACGCTTAACGAMAAA 3 corresponding to nucleotides 1-15 of the reference Pasteur virus strain (PV) (Tordo et al., 1986a) for the priming in the cDNA synthesis. A combination of these primers was used for amplification of the partial $\mathrm{N}$ gene Lys001 (+), 550B (-) (647-666), 304 (-) (1514-1533) (Markotter et al., 2006). The PCR reactions were undertaken with an ABI 9700 thermocycler with the following thermocycling conditions, initial denaturation at $94^{\circ} \mathrm{C}$ for $1 \mathrm{~min}$, followed by 40 cycles of $94^{\circ} \mathrm{C}$ for $30 \mathrm{~s}, 37^{\circ} \mathrm{C}$ for $30 \mathrm{~s}, 72^{\circ} \mathrm{C}$ for $90 \mathrm{~s}$ and a final extension at $72^{\circ} \mathrm{C}$ for 7 minutes. The amplicons were visualized and evaluated under UV light after electrophoresis in 1\% ethidium bromide stained agarose gels. The amplicons were gel purified using Wizard PCR purification system (Promega, Madison, WI, USA) according to supplier's protocol prior to sequencing.

\section{Nucleotide sequencing and Phylogenetic analysis}

The purified amplicons were cycle sequenced using ABI PRISM Big Dye Terminator v3.1 sequencing kit, (Applied Biosystem, USA) according to supplier's protocol. This was performed in a thermocycler (Gene Amp PCR System 9700, Applied Biosystem); with the same primers as in the amplification step with the following cycling conditions $96^{\circ} \mathrm{C}$ for $1 \mathrm{~min}, 50^{\circ} \mathrm{C}$ for $50 \mathrm{~s}, 60^{\circ} \mathrm{C}$ for $4 \mathrm{~min}$ for 25 cycles. The sequencing products were further analysed using ABI 3100 DNA analyzer.

Nucleotide sequences generated were manually edited and a consensus sequence obtained after the forward and reverse sequences were aligned using the Bio-Edit program (Hall, 1999) and multiple alignments undertaken with the Clustal $X$ version 1.82 package (Thompson et al., 1997). Phylogenetic analysis was performed with MEGA 4.1 version (Tamura et al., 2007) and a neighbor-joining tree was constructed as described previously (Saitou and Nei, 1987). Bootstrap values were estimated based on 1000 replicates and values above 70\% were considered significant (Hillis and Bull, 1993). The TREEVIEW Program (Page, 1996) was used to illustrate the graphical output. Nucleotide sequences obtained in this investigation were submitted to the GenBank and the accession numbers are shown in Table I 
Table I: Rabies viruses used in the phylogenetic study

\begin{tabular}{|c|c|c|c|c|c|c|c|}
\hline $\begin{array}{l}\text { Virus } \\
\#\end{array}$ & Lab \# & $\begin{array}{l}\text { Locality of } \\
\text { origin }\end{array}$ & $\begin{array}{l}\text { Species } \\
\text { of origin }\end{array}$ & $\begin{array}{l}\text { Year of } \\
\text { isolation }\end{array}$ & Reference & Lat-long & Genbank \# \\
\hline 1. & RD172/06 & Kastina & Dog & 2006 & This study & $12^{\circ} 59^{\prime}-7^{\circ} 36$ & EU888716 \\
\hline 2. & RD94/07 & Foron & Dog & 2007 & This study & $9^{\circ} 41^{\prime}-8^{\circ} 56^{\prime}$ & EU888687 \\
\hline 3. & RD138/06 & Stray & Dog & 2006 & This study & Unknown & EU888703 \\
\hline 4. & RD33/06 & Bukuru & Dog & 2006 & This study & $9^{\circ} 47^{\prime}-8^{\circ} 51$ & EU888657 \\
\hline 5. & RD188/06 & Quaanpan & Dog & 2006 & This study & $9^{\circ} 26^{\prime}-8^{\circ} 54^{\prime}$ & EU888726 \\
\hline 6. & RD159/06 & Jos & Dog & 2006 & This study & $9^{\circ} 54^{\prime}-8^{\circ} 53^{\prime}$ & EU888707 \\
\hline 7. & RD16/07 & Fadakarshe & Dog & 2007 & This study & $9^{\circ} 47^{\prime} \quad 8^{\circ} 17^{\prime}$ & EU888650 \\
\hline 8. & RD47/07 & Jos & Cat & 2007 & This study & $9^{\circ} 54^{\prime} \quad 8^{\circ} 53^{\prime}$ & EU888662 \\
\hline 9. & RD17/07 & Jos & Dog & 2007 & This study & $9^{\circ} 54^{\prime}-8^{\circ} 53^{\prime}$ & EU888651 \\
\hline 10. & RD58/06 & Lagos & Dog & 2006 & This study & $6^{\circ} 29^{\prime}-3^{\circ} 21^{\prime}$ & EU888665 \\
\hline 11. & RD14/07 & BarkiLadi & Dog & 2007 & This study & $9^{\circ} 32^{\prime}-8^{\circ} 53^{\prime}$ & EU888649 \\
\hline 12. & RD38/05 & Riyom & Dog & 2005 & This study & $9^{\circ} 37^{\prime}-8^{\circ} 45^{\prime}$ & EU888658 \\
\hline 13. & RD158/06 & Jos & Dog & 2006 & This study & $9^{\circ} 54^{\prime}-8^{\circ} 53^{\prime}$ & FJ435701 \\
\hline 14. & RD166/06 & Mangu & Dog & 2006 & This study & $9^{\circ} 18^{\prime} 09^{\prime} 9^{\circ} 11^{\prime} 34^{\prime}$ & EU888713 \\
\hline 15. & RD79/07 & Mangu & Dog & 2007 & This study & $9^{\circ} 18^{\prime} 09^{\prime} 9^{\circ} 11^{\prime} 34^{\prime}$ & EU888681 \\
\hline 16. & RD181/06 & Bokkos & Dog & 2006 & This study & $9^{\circ} 18^{\prime} \quad 9^{\circ} 00^{\prime}$ & EU888721 \\
\hline 17. & RD124/07 & Mangu & Dog & 2007 & This study & $9^{\circ} 18^{\prime} 09^{\prime}-9^{\circ} 11^{\prime} 34^{\prime}$ & EU888697 \\
\hline 18. & RD122/07 & Mangu & Dog & 2007 & This study & $9^{\circ} 18^{\prime} 09^{\prime}-9^{\circ} 11^{\prime} 34^{\prime}$ & EU888695 \\
\hline 19. & $\mathrm{RD} 2 / 08$ & Mangu & Dog & 2008 & This study & $9^{\circ} 18^{\prime} 09^{\prime}-9^{\circ} 11^{\prime} 34^{\prime}$ & EU888643 \\
\hline 20. & RD177/06 & Bauchi & Dog & 2006 & This study & $10^{\circ} 30^{\prime}-9^{\circ} 50^{\prime}$ & FJ435700 \\
\hline 21. & RD60/05 & Mangu & Dog & 2005 & This study & $9^{\circ} 18^{\prime} 09^{\prime}-9^{\circ} 11^{\prime} 34^{\prime}$ & EU888666 \\
\hline 22. & $13136 / 89$ & Zaria & Dog & 1989 & This study & $11^{\circ} 04^{\prime}-7^{\circ} 42^{\prime}$ & EU888729 \\
\hline 23. & RD173/06 & Jos & Dog & 2006 & This study & $9^{\circ} 54^{\prime} \quad 8^{\circ} 53^{\prime}$ & EU888717 \\
\hline 24. & RD123/07 & Markurdi & Dog & 2007 & This study & $7^{\circ} 43^{\prime} 8^{\circ} 32^{\prime}$ & EU888696 \\
\hline 25. & RD48/07 & Lafia & Dog & 2007 & This study & $9^{\circ} 28^{\prime} 8^{\circ} 53^{\prime}$ & EU888663 \\
\hline 26. & RD80/07 & Jos & Dog & 2007 & This study & $9^{\circ} 54^{\prime}-8^{\circ} 53^{\prime}$ & EU888682 \\
\hline 27. & RD168/06 & Bauchi & Dog & 2006 & This study & $10^{\circ} 30^{\prime}-9^{\circ} 50^{\prime}$ & EU888714 \\
\hline 28. & RD71/07 & Kagoro & Dog & 2007 & This study & $9^{\circ} 34^{\prime} 60^{\prime} 8^{\circ} 30^{\prime}$ & EU888675 \\
\hline 29. & RD30/07 & Jos & Dog & 2007 & This study & $9^{\circ} 54^{\prime}-8^{\circ} 53^{\prime}$ & EU888656 \\
\hline 30. & RD10/07 & Ibadan & Dog & 2007 & This study & $7^{\circ} 22^{\prime} \quad 3^{\circ} 53^{\prime}$ & EU888647 \\
\hline 31 & RD11/07 & Ibadan & Dog & 2007 & This study & $7^{\circ} 22^{\prime}-3^{\circ} 53^{\prime}$ & EU888648 \\
\hline 32. & RD44/07 & Stray & Dog & 2007 & This study & Unknown & EU888660 \\
\hline 33. & RD99/06 & Abeokuta & Goat & 2006 & This study & $7^{\circ} 09^{\prime}-3^{\circ} 20^{\prime}$ & EU888689 \\
\hline $34^{*}$ & RV629 & Nigeria & Human & 1996 & $\begin{array}{l}\text { Johnson et } \\
\text { al., } 2002\end{array}$ & Unknown & AY103008 \\
\hline
\end{tabular}

Key* Sequence obtained from the Genbank

\section{RESULTS}

The phylogenetic analyses were performed after nucleotide sequence determination of amplified products with the expected band size of $606 \mathrm{bp}$ using thirty-three representative viruses from a panel of 100 viruses. In this analysis was included a single human sequence from the Genbank. These data revealed that the viruses included in the analyses were very closely related with at least 99\% sequence identity based on Kimura-2 parameter model using the MEGA programme] (Tamura et al., 2007).

All the viruses were found to belong to the African 2 dog lineage (Kissi et al., 1995) the main variant found to be circulating in dogs in the west African sub-region. Two major subgroups supported by bootstrap values of $(100 \%$ and $75 \%$, cluster 1 and 2 ) were identified despite the close relatedness of the viruses. The sequence of a virus retrieved from the Genbank (Johnson et al.,2002) and recovered from woman originating from Nigeria who succumbed to rabies infection in Britain clustered with viruses from Ibadan (cluster 2). On average, the rabies viruses showed $13.2 \%$ sequence divergence from the Pasteur virus (PV).

Phylogenetic data from the NJ tree (fig. 1) was validated with other algorithms including maximum parsimony (MP) and maximum likelihood (ML) and produced trees with similar topologies. 


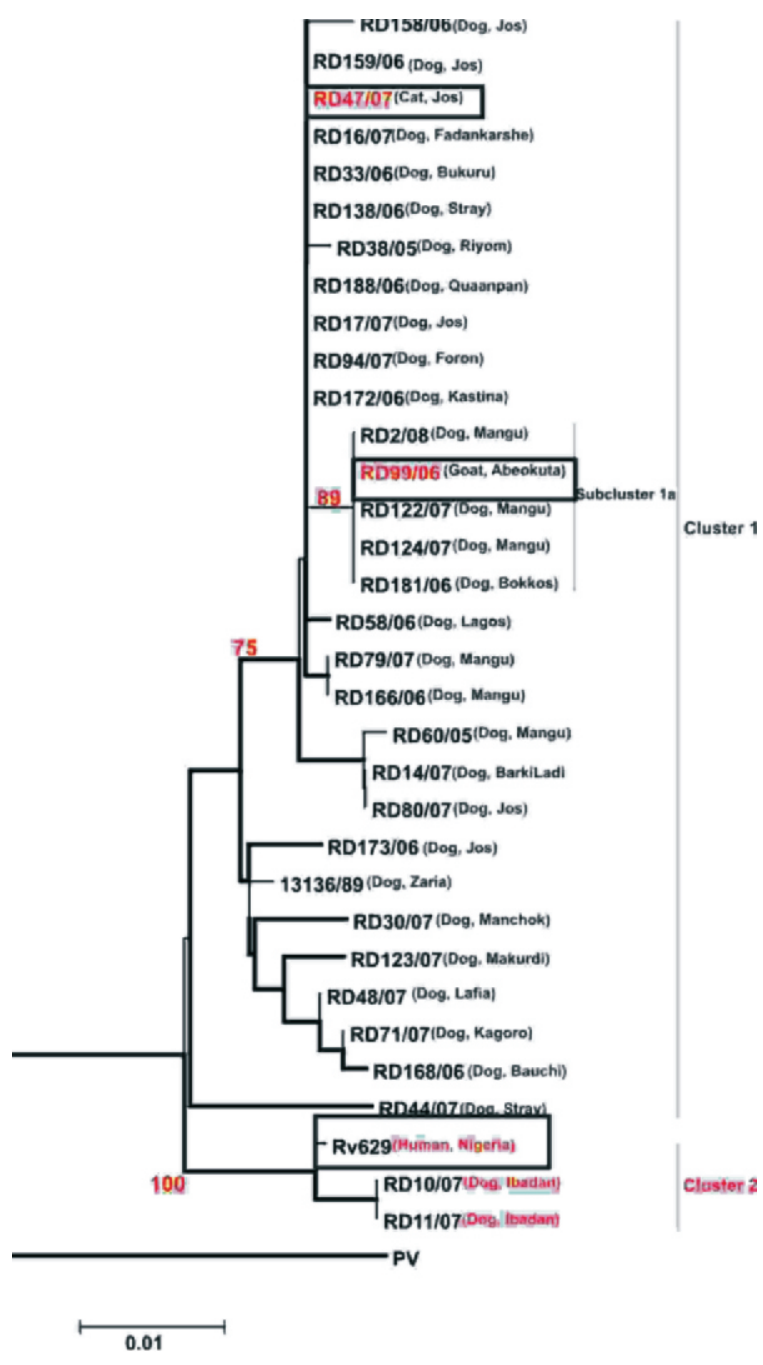

Figure 1: Neighbour-joining phylogenetic tree of 33 rabies viruses from Nigeria. Bootstrap support values were obtained from 1000 replicates and the scale bar represents nucleotide substitution per site. PV was used to root the tree and the vertical branches are set for clarity

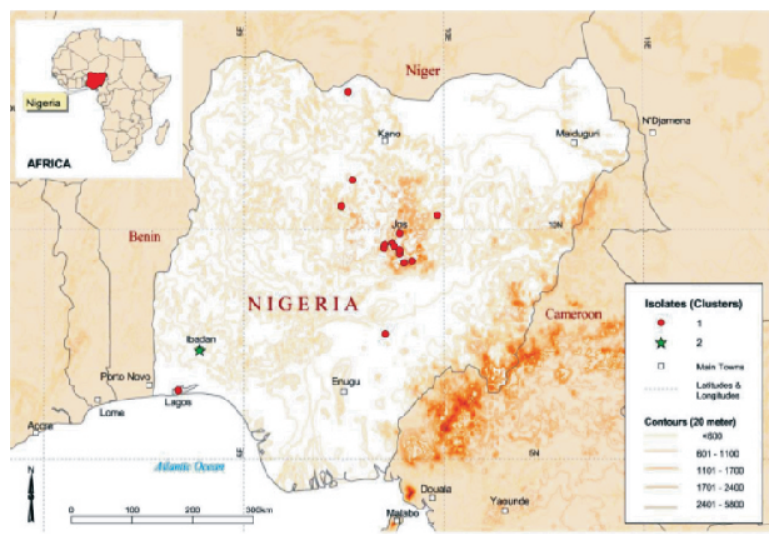

Figure 2: A map of Nigeria illustrating the geographic distribution of the representatives of the virus isolates in the clusters obtained in the study (Geographic_information_system)

\section{DISCUSSION}

During the early 1900s human rabies was first officially documented (Boulger and Hardy, 1960) in Bonny and Eket, the southern coastal parts of Nigeria but now has spread virtually to all geographical zones of the country (Ogunkoya et al., 1984; Ezekoli and Umoh, 1987). This study has confirmed that the use of molecular technique such as nucleotide sequencing and phylogenetics can be useful in tracing the origin of infectious pathogens such as rabies.

The results presented here indicate that the rabies viruses in the study panel were very closely related with over $99 \%$ nucleotide similarity. These viruses grouped into one dominant genetic variant (cluster 1) which further support the notion of a single progenitor for the West African rabies viruses (Kissi et al., 1995). The sequence obtained from the Genbank recovered from a Nigerian woman who died of rabies in the UK was very similar to those obtained from infected dogs from Ibadan in the south west of the country suggesting that this woman was probably exposed in this locality before her travel to Europe.

This finding further emphasise rabies as a travel disease and secondly the utility of phylogenetics in tracing the transmission patterns of infectious diseases. The domestic dog evidently remains the prime maintenance host species and largely responsible for transmitting rabies to humans and other domestic animal as described in some earlier studies (Fagbami et al., 1981). In the process, spill-over events take place to include animals such goat and cat. Isolation of a rabies virus strain from a goat from the south west of Nigeria which clustered with the subcluster $1 \mathrm{a}$ group from the north could likely be linked to human activities such as seasonal migration of pastoralists from north to south as well as movement of animals for commercial purposes. The identification of subcluster 1a with high bootstrap value of $89 \%$ could suggest to a local rabies outbreak in this locality where there is high concentration of dogs and activities causing local translocation of these dogs due to cultural beliefs and practices of the indigenous people (Oboegbulem, 1994).

In conclusion, findings from this study have demonstrated why we must control rabies in dogs in this country. This is to protect humans and other susceptible animals especially those 
which form part of food security and a source of income to many rural households. There is also the need to increase vaccination coverage of dogs so as to break the cycle of infection in these species. It is further and urgently recommended that steps have to be taken towards controlling strays and more importantly raise awareness regarding the need to seek prompt medical attention when exposed.

\section{ACKNOWLEDGEMENT}

This work was funded in part by International Society for Infectious Diseases (ISID) Small Grant 2007, the Poliomyelitis Research Foundation (PRF grant \#08/59) and Department Veterinary Tropical Diseases, University of Pretoria, South Africa. The authors gratefully acknowledge the former Executive Director of NVRI, Vom, Dr (Mrs) L.H. Lombin and the Director of Research, Dr David Shamaki for the isolates used in the study.

\section{REFERENCES}

BOULGER, L. R. and HARDY, J. (1960): Rabies in Nigeria. West Afr Med J., 9: 223-234.5.

DEAN, D.J., ABELSETH, M.K., ATAANASIA, P., (1996): The fluorescent antibody tes (FAT). In: Meslin, F.X., Kaplan, M.M., Koprowski, H (Eds.), LaboratoryTechniques in Rabies, fourth ed. World Health Organisation, Geneva, 88-95.

EZEOKOLI, C. D. and UMOH, J. U. (1987): Epidemiology of rabies in Northern Nigeria. Trans $R$ Soc Trop Med Hyg, 81: 268-272.

FAGBAMI, A. H., ANOSA, V. O. and EZEBUIRO, E. O. (1981): Hospital records of human rabies and antirabies prophylaxis in Nigeria. Trans $R$ Soc Trop Med Hyg., 75: 872-876.

HALL, T.A. (1999): BioEdit: a user-friendly biological sequence alignment editor and analysis program for Windows 95/98/NT. Nucl. Acids. Symp. Ser. 41:9598.

HILLS, D. M. and BULL, J. J. (1993): An empirical test of bootstrapping as a method or assessing confidence in phylogenetic analysis. Systematic Biol, 42: 182192.

JOHNSON, N., LIPSCOMB, D. W., STOTT, R., RAO, G.G., MANSFIELD, K., SMITH, J., MCELHINNEY, L. and. FOOKS, A. R. (2002): Investigation of a human case of rabies in the United Kingdom. $J$ Clin Virol., 25: 351- 356.

KISSI, B., TORDO, N. and BOURHY, H. (1995): Genetic polymorphism in the rabies virus nucleoprotein gene Virology, 209: 526-537

KNOBEL, D. L., CLEAVELAND, S., COLEMAN, P. G., FEVRE, E. M., MELTZER, M. I., MIRANDA, E. G., SHAW, A., ZINSSTAG, J. and MESLIN, F. (2005): Re- evaluating the burden of rabies in Africa and Asia. Bull World Health Organ., 83: (5)1-13.

PAGE, R.D.M. (1996): TREEVIEW: an application to display phylogenetic trees on personal computers. Computer Application in the Biosci., 12: 357-358.

MARKOTTER, W., IVAN KUZMIN, I., RUPPRECHt, C.E., RANDLES, R., SABETA, C.T., ALEXANDEr I. WANDELEr, A.I. and NEL, L.H. (2006): Isolation of Lagos Bat Virus from Water Mongoose. Emerg Infect Dis., www.cdc.gov/eid 12: 1913- 1918.

NAWATHE, D. R. (1980): Rabies control in Nigeria. Bulletin Office International des pizooties, 92: 129130.

OBOEGBULEM, S. I. (1994): Rabies in man and animals. Fidelity Publishers, Enugu. 238 pp.4.

OGUNKOYA, A. E.; WILL, A. E and EZEOKOLI, C. O.(1984): Rabies in Oyo State, Nigeria 1971-1984,. Int J Zoonoses., 11: 84 - 95.

SABETA, C. T., MANSFIELD, K. L. MCELHINEY, L. M., FOOKS, A. R. and NEL, L. H. (2007): Molecular epidemiology of rabies in bat-eared foxes (Otocyon megalotis) in South Africa. Virus Res., 129: 1-10.

SAITOU, N. and NEI, M. (1987): The neighbour-joining method: A new method for reconstructing phylogenetic trees. Molecular Biology and Evolution, , 4: 406-425.

TAMURA, K. DUDLEY, J., NEI M and KUMAR, S. (2007). MEGA4: Molecular Evolutionary Genetics Analysis (MEGA) software version 4.1. Molecular Biology and Evolution, 24:1596-1599.

THOMPSON, J. D., GIBSON, T. J., PLEWNIAK, F. JEANMOUGIN, F. and HIGGINS, D. G. (1997): The CLUSTAL_X windows interface: flexible strategies for multiple sequence alignment aided by quality analysis tools. Nucleic Acids Res., 25: 4876-4882.

TORDO,N., POCH, O., ERMINE, A. and KEITH, G. (1986a): Primary structure of leader RNA and nucleoprotein genes of the rabies genome: Segmented homology with VSV., Nucleic Acids Res., 14: 2671-2683.

TORDO, N. (1996a); Characteristics and molecular biology of the rabies virus. In: Laboratory techniques in rabies. F-X Meslin, M. M. Kaplan and $\mathrm{H}$. Koprowski (ed.). World Health Organization, Geneva: pp 28-51.

TORDO, N, SACRAMENTO, D. and BOURHY, $\mathrm{H}$. (1996b): The polymerase chain reaction (PCR) technique for diagnosis, typing and epidemiological studies of rabies. In: Laboratory techniques in rabies. F-X. Meslin, M. M. Kaplan and H. Koprowski (eds.). Geneva. Switzerland: World Health Organization. 157-174.

TORDO, N., BAHLOUl, Y., JACOB, C., JALLET, P. and PERRIN, H. (2006): Rabies: epidemiological tendencies and control tools. Dev Biol., 125: 3-13.

UMOH, J.U. and BELINO, E. D. (1978): Rabies in Nigeria: A Historical Review. Int J Zoonosis., 6: 41-48.

WORLD HEALTH ORGANIZATION. (2005): Expert Consultation on rabies. Technical Report Series 931. 